Article

\title{
Synthesis of SAPO-35 molecular sieve and its catalytic properties in the methanol-to-olefins reaction
}

\author{
LI Bing a, TIAN Peng a , LI Jinzhe a, CHEN Jingrun a,b, YUAN Yangyang a,b, SU Xiong a,b, FAN Dong a,b, \\ WEI Yingxu a, QI Yue a, LIU Zhongmin a,* \\ a Dalian National Laboratory for Clean Energy, National Engineering Laboratory for Methanol-to-Olefins, Dalian Institute of Chemical Physics, Chinese \\ Academy of Sciences, Dalian 116023, Liaoning, China \\ b University of Chinese Academy of Sciences, Beijing 100049, China
}

\section{A R T I C L E I N F O}

\section{Article history:}

Received 30 December 2012

Accepted 30 January 2013

Published 20 April 2013

\section{Keywords:}

SAPO-35

Methanol to olefins

SAPO-34

Coke species

Deactivation

\section{A B S T R A C T}

SAPO-35 molecular sieve samples with different $\mathrm{Si}$ contents were hydrothermally synthesized using hexamethyleneimine as the template and characterized by XRD, XRF, SEM, MAS NMR, XPS and $\mathrm{N}_{2}$ physisorption. Three SAPO-35 samples were tested as methanol-to-olefins catalysts. After the reaction, the evolution of coke species was investigated over SAPO-35 and SAPO-34 catalysts with similar Si concentrations. A correlation between the cage size of the molecular sieves and the coke species was obtained.

(C) 2013, Dalian Institute of Chemical Physics, Chinese Academy of Sciences. Published by Elsevier B.V. All rights reserved.

\section{Introduction}

Silicoaluminophosphate molecular sieves (SAPO- $n$ ) were first synthesized and reported by Union Carbide Corporation (UCC) in 1984 [1]. Due to their mild acidity and special pore structures, SAPO molecular sieves have widespread applications in the chemical industry [2]. SAPO-35, as a member of the family with the levyne-like crystal structure (LEV), is a small pore molecular sieve with a pore diameter of $3.6 \mathrm{~nm} \times 4.8 \mathrm{~nm}$. The framework of SAPO-35 comprises levyne cages connected by single six-membered rings and double six-membered rings. There are two distinct $\mathrm{T}$ sites in the framework: one is in the double six-membered ring and the other is in the single six-membered ring. The distribution of these two sites is in the ratio of 2:1 [3]. Due to the special structure of SAPO-35, it has been employed as the catalyst in methanol conversion and aminomethylation [4-7]. Moreover, SAPO-35 is also explored as an adsorbent for $\mathrm{CO}_{2} / \mathrm{CH}_{4}$ separation $[8,9]$.

The methanol-to-olefins (MTO) process is the key process to produce light olefins from coal or natural gas. The molecular sieves ZSM-5 and SAPO-34 with eight-membered ring and CHA cages exhibit excellent catalytic performance in the reaction $[6,7,10-12]$. Other small pore molecular sieves with the eight-membered pore size such as SAPO-17, SAPO-18, and SAPO-35 have also been explored as catalysts for the MTO reaction [7,13,14]. The SAPO-35 molecular sieve showed a faster coking deactivation rate compared with SAPO-34 [4,6]. At present, the correlations between the deactivation process (deposited coke species) and the reaction conditions (such as time and temperature) during the MTO reaction over the SAPO-34 catalyst are relatively clear $[15,16]$. However, there is no report so far on the deactivation process during methanol conversion

\footnotetext{
*Corresponding author. Tel/Fax: +86-411-84379335; E-mail: liuzm@dicp.ac.cn 
catalyzed by SAPO-35. It is speculated that the activity differences between SAPO-34 and SAPO-35 are due to their different structures. Research on the deactivation during the MTO reaction over SAPO-35 will help understand the effect of the cage structures of the molecular sieves and the deposited coke spices.

In this work, SAPO-35 molecular sieves with different Si contents were hydrothermally synthesized by using hexamethyleneimine as the template. The effect of Si content on the physical and chemical properties of the molecular sieves was studied in detail. In addition, three SAPO-35 molecular sieves with different Si contents were chosen as MTO catalysts to investigate the effects of the acidity on the reaction. The evolution of the coke species in the reaction was investigated over both SAPO-35 and SAPO-34 catalysts with similar Si concentrations. The correlation between the cage size of the molecular sieves and deactivation due to the coke species is discussed.

\section{Experimental}

\subsection{Synthesis of molecular sieves}

The SAPO-35 molecular sieves were synthesized as reported elsewhere [17]. Pseudoboehmite powder $\left(w\left(\mathrm{Al}_{2} \mathrm{O}_{3}\right)=70\right.$ $w t \%)$, sol $\left(w\left(\mathrm{SiO}_{2}\right)=31.1 \mathrm{wt} \%\right)$ and phosphoric acid $\left(w\left(\mathrm{H}_{3} \mathrm{PO}_{4}\right)\right.$ $=85 \mathrm{wt} \%$ ) were the aluminum source, silicon source, and phosphorus source, respectively. Hexamethyleneimine (HMI, chemical pure) was used as the template agent. The molar ratio of reactants was $0.96 \mathrm{P}_{2} \mathrm{O}_{5}: 1.0 \mathrm{Al}_{2} \mathrm{O}_{3}: n \mathrm{SiO}_{2}: 1.51 \mathrm{HMT}: 55.47 \mathrm{H}_{2} \mathrm{O}$ ( $n=0.1,0.2,0.3,0.5,0.8,1.0$ ). The detailed procedure was as follows. Into a beaker, deionized water, aluminum source, silicon source, phosphorus source, and HMI were sequentially added with vigorous stirring to make the initial gel homogeneous. This was then transferred into a $100 \mathrm{ml}$ stainless steel reactor, which was then sealed and heated at $200{ }^{\circ} \mathrm{C}$ for $24 \mathrm{~h}$. After crystallization, the product was collected by centrifugal separation, rinsed with water until the $\mathrm{pH}$ level was neutral, and then dried at $120^{\circ} \mathrm{C}$. The samples with different Si contents were denoted as $0.1 \mathrm{Si}, 0.2 \mathrm{Si}, 0.3 \mathrm{Si}, 0.5 \mathrm{Si}, 0.8 \mathrm{Si}$, and $1.0 \mathrm{Si}$.

\subsection{Characterization}

X-ray powder diffraction (XRD) measurements were performed using a PANalytical X'Pert PRO X-ray diffractometer with $\mathrm{Cu}$ anode, $K_{\alpha}$ radiation $(\lambda=0.15418 \mathrm{~nm})$, voltage of $40 \mathrm{kV}$ and current of $40 \mathrm{~mA}$. The elemental analysis was carried out using a Philips Magix 2424X X-ray Fluorescence Spectrometer (XRF). Morphology images were acquired on a Hitachi S-3400N scanning electron microscopy (SEM). X-ray photoelectron spectroscopy (XPS) was determined employing a Thermo ESCALAB 250Xi X-ray photoelectron spectrometer with $\mathrm{Al} K_{\alpha}$ radiation. The peak of $\mathrm{Al} 2 p$ at $74.7 \mathrm{eV}$ from $\mathrm{Al}_{2} \mathrm{O}_{3}$ on the surface of the samples was used as the internal standard. $\mathrm{N}_{2}$ adsorption measurement was performed on a Micromeritics ASAP 2010 volumetric adsorption analyzer.

${ }^{1} \mathrm{H}$ MAS NMR experiments were performed on a Bruker Avance III-600 solid phase NMR spectrometer with a proton resonance frequency of $600.13 \mathrm{MHz}$ by using a $4 \mathrm{~mm}$ probe head. One pulse program was used and the $\pi / 2$ pulse length was $4.4 \mu \mathrm{s}$. The recycle delay time is $10 \mathrm{~s}$. The spin rate was 12 $\mathrm{kHz}$ with 32 times sampling frequency. Before the ${ }^{1} \mathrm{H}$ MAS NMR experiments, all samples underwent vacuum dehydration at $400{ }^{\circ} \mathrm{C}$ and $<10^{-3} \mathrm{~Pa}$ for $20 \mathrm{~h}$ to remove water and impurities in the molecular sieve. The samples were transferred in a nitrogen-filled glove box to the NMR rotator for testing. The quantitative processing of the ${ }^{1} \mathrm{H}$ MAS NMR data was as follows. A calibration curve for the correlation between peak areas and mass of sample were first made by using adamantine as the external standard. Then the ${ }^{1} \mathrm{H}$ MAS NMR spectra of the sample with known mass were acquired under identical acquisition conditions. The peak areas of Brönsted acid sites was calculated by Gauss-Lowrance linear fitting to get the density of Brönsted acid sites of the samples from the calibration curve.

\subsection{Reaction evaluation}

The catalytic properties of the molecular sieves were evaluated using an atmospheric fixed bed equipment. $1.2 \mathrm{~g}$ calcined sample (40-60 mesh) was packed in the reactor, which was then purged with nitrogen at $520{ }^{\circ} \mathrm{C}$ for $30 \mathrm{~min}$. After purging, methanol solution ( $40 \mathrm{wt} \%$ ) was injected into the reactor by a pump. The products were analyzed online using an Agilent 7890A gas chromatograph (GC) with PoraPLOT Q-HT capillary column and FID detector.

\subsection{Collections of coke deposits and analysis of coke species}

The deposited coke species were collected by stopping the feed after a pre-determined reaction time, unloading the catalysts quickly and then quenching in liquid nitrogen.

The Guisnet method was used for the qualitative analysis of the coke species $[18,19]$. In a Teflon bottle, $50 \mathrm{mg}$ of catalyst was added to $1 \mathrm{ml} \mathrm{HF}$ water solution (20 wt\%). After the mixture was shaken well and allowed to sit for $1 \mathrm{~h}, 0.5 \mathrm{ml} \mathrm{di}$ chloromethane was added into the solution. 5 min later, $\mathrm{NaOH}$ was added and mixed well. The mixture was then transferred to a separatory funnel and shaken vigorously. The lower layer liquid was collected into a sample vial for GC testing by an Agilent 7890-5975C MSD gas chromatograph-mass spectrometer with a HP-5 capillary column. Each compound was identified using the NIST 08 library.

\section{Results and discussion}

\subsection{Synthesis and characterization of SAPO-35 with different Si contents}

The XRD results of the samples are shown in Fig. 1. All the SAPO-35 molecular sieves with different Si contents had the LEV framework structure, as shown by comparing to the standard pattern $[7,20]$. The relative crystallinity, relative yield, and chemical composition of the SAPO-35 samples with different Si contents are listed in Table 1 . The solid yield of the samples increased with increasing amount of $\mathrm{SiO}_{2}$ in the initial gels. 


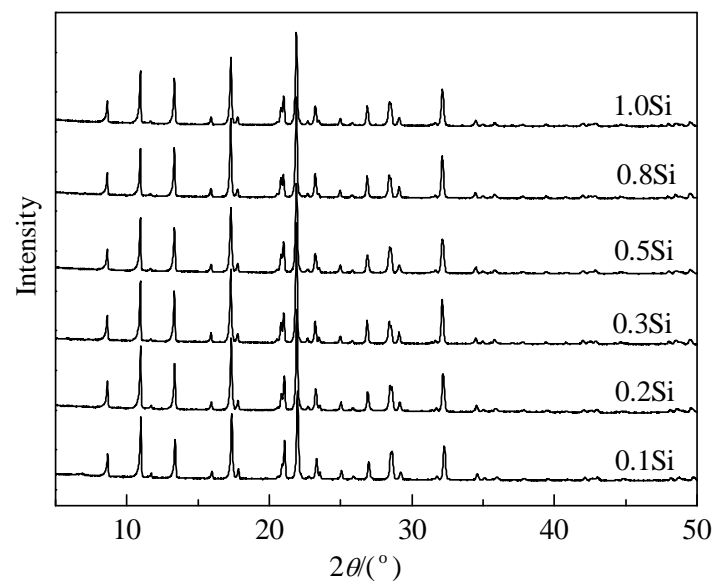

Fig. 1. XRD patterns of the SAPO-35 samples with different Si contents.

However, the crystallinity exhibited first an increase then a decrease trend. 0.3Si sample showed the highest crystallinity. In our previous research on the synthesis of SAPO-34, we also found that samples with $0.2-0.3 \mathrm{Si}$ contents had the highest crystallinity [21]. This suggested that the $\mathrm{Si}$ content in the initial gel not only affected the chemical composition of the samples but also the crystallinity. In addition, the XRF elemental analysis results indicated that the Si content of SAPO-35 increased with the increase of Si content in the initial gel. To better correlate the Si contents of the starting materials and products, we introduce a concept of "silicon incorporation" defined as $[\mathrm{Si} /(\mathrm{Si}+\mathrm{Al}+\mathrm{P})]_{\text {product }} /[\mathrm{Si} /(\mathrm{Si}+\mathrm{Al}+\mathrm{P})]_{\text {gel }}$ (shown in Table 1$)$. A descending tendency was found for silicon incorporation in SAPO- 35 with the increase of Si content in the starting materials. The 0.1Si sample exhibited the highest silicon incorporation of 1.82. The silicon incorporation decreased to less than 1.0 when the Si content of the initial gel was more than 0.3. Silicon incorporation was only 0.7 when the Si content of the initial gel was 1.0. Therefore, we believed that it is the high silicon incorporation associated with the samples with low $\mathrm{Si}$ contents that resulted in their relatively low solid yields. Catlow et al. [22]. employed lattice simulation to calculate the energy changes of
Table 1

Relative crystallinity and chemical composition of the SAPO-35 samples with different Si contents.

\begin{tabular}{lcccc}
\hline Sample & $\begin{array}{c}\text { Relative } \\
\text { crystallinity (\%) }\end{array}$ & $\begin{array}{c}\text { Relative } \\
\text { yield (\%) }\end{array}$ & $\begin{array}{c}\text { Molar } \\
\text { composition }\end{array}$ & $\begin{array}{c}\mathrm{Si} \\
\text { incorporation* }\end{array}$ \\
\hline $0.1 \mathrm{Si}$ & 84 & 62 & $\mathrm{Si}_{0.060} \mathrm{Al}_{0.490} \mathrm{P}_{0.450}$ & 1.82 \\
$0.2 \mathrm{Si}$ & 94 & 74 & $\mathrm{Si}_{0.079} \mathrm{Al}_{0.497} \mathrm{P}_{0.424}$ & 1.25 \\
$0.3 \mathrm{Si}$ & 100 & 86 & $\mathrm{Si}_{0.092} \mathrm{Al}_{0.485} \mathrm{P}_{0.423}$ & 1.01 \\
$0.5 \mathrm{Si}$ & 94 & & $\mathrm{Si}_{0.122} \mathrm{Al}_{0.487} \mathrm{P}_{0.391}$ & 0.89 \\
$0.8 \mathrm{Si}$ & 91 & 95 & $\mathrm{Si}_{0.169} \mathrm{Al}_{0.465} \mathrm{P}_{0.367}$ & 0.80 \\
$1.0 \mathrm{Si}$ & 85 & 100 & $\mathrm{Si}_{0.175} \mathrm{Al}_{0.457} \mathrm{P}_{0.368}$ & 0.70 \\
\hline *Define & & &
\end{tabular}

*Defined as the molar ratio of $[\mathrm{Si} /(\mathrm{Si}+\mathrm{Al}+\mathrm{P})]_{\text {product }} /[\mathrm{Si} /(\mathrm{Si}+\mathrm{Al}+\mathrm{P})]_{\text {gel }}$.

silicon incorporation in the framework of SAPO-5 molecular sieves and found that highly dispersed and singly substituted silicon was the most stable, followed $5 \mathrm{Si}$ and $8 \mathrm{Si}$ islands. These results suggested that the energy of $\mathrm{Si}$ incorporation in the framework increased with increasing content of substituted silicon, leading to the decreasing ability for silicon incorporation in the framework. Their conclusion is consistent with our experimental results.

The SEM images of the samples with different Si contents are shown in Fig. 2. The SAPO-35 grains presented the typical rhombohedral morphology, but the change of silicon content had a significant effect on the surface roughness of the molecular sieve crystals. With a low silicon content, the molecular sieve surface was relatively smooth. The crystal surface became rough and irregular small holes appeared when the silicon content was increased to 0.8 . When the silicon content was 1.0, the surface of the crystal was wrapped by small particles and it showed a 'core-shell' structure, which presumably resulted from a secondary crystal growth on the rough surface of the crystal or the enrichment of excessive amorphous silica in the gel on the crystal surface. The surface compositions of the $0.5 \mathrm{Si}$ and 1.0Si samples were analyzed by XPS (Table 2). It was found that the crystal surface of these two samples comprised silica, phosphorus oxide, and alumina. The relative silicon content of the surface was higher than that of the bulk phase, and the enrichment of silicon on the high silicon content sample surface was higher. It was thus speculated that the shell of the $1.0 \mathrm{Si}$

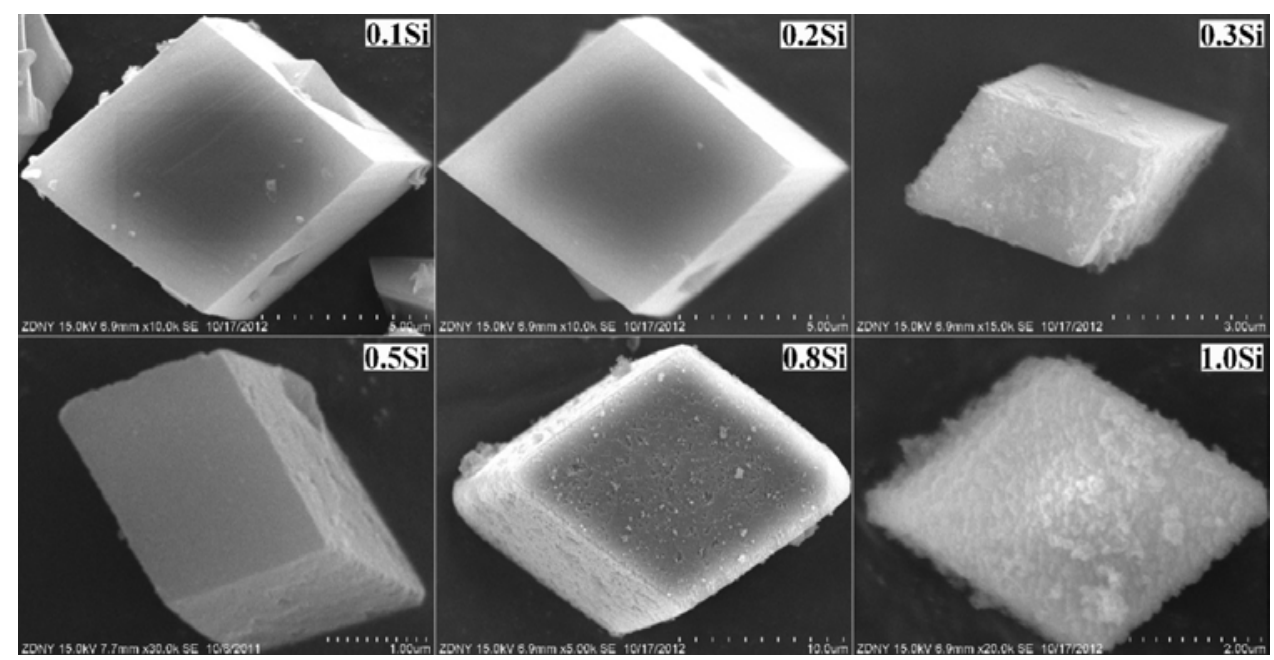

Fig. 2. SEM images of the SAPO-35 samples with different Si contents. 
Table 2

Bulk and surface compositions of the SAPO-35 samples with different Si contents.

\begin{tabular}{lccc}
\hline \multirow{2}{*}{ Sample } & \multicolumn{2}{c}{ Composition } & \multirow{2}{*}{$\mathrm{Si}_{\text {surface }} / \mathrm{Si}_{\text {bulk }}$} \\
\cline { 2 - 3 } & $\mathrm{Bulk}$ & Surface & 1.46 \\
\hline $0.5 \mathrm{Si}$ & $\mathrm{Si}_{0.122} \mathrm{Al}_{0.487} \mathrm{P}_{0.391}$ & $\mathrm{Si}_{0.178} \mathrm{Al}_{0.478} \mathrm{P}_{0.335}$ & 1.46 \\
$1.0 \mathrm{Si}$ & $\mathrm{Si}_{0.175} \mathrm{Al}_{0.457} \mathrm{P}_{0.368}$ & $\mathrm{Si}_{0.275} \mathrm{Al}_{0.405} \mathrm{P}_{0.320}$ & 1.58 \\
\hline
\end{tabular}

sample grains was formed by a secondary crystal growth on the rough surface of the crystal. Meanwhile, from the silicon enrichment on the SAPO-35 crystal surface revealed by XPS, we can suppose that the distribution of silicon in the SAPO-35 crystals was non-uniform and there was a gradual increase of the silicon content from the inside outwards. We also found a similar situation in the crystallization of SAPO-34 with diethylamine as a template agent [23]. The main reason would be the gradual increase of the gel $\mathrm{pH}$ during the synthesis of SAPO molecular sieves. The increase of $\mathrm{pH}$ promoted depolymerization of the silicon source in the gel system, thus the ability for silicon incorporation into the molecular sieve framework was enhanced (the pH value of the gel in our synthesis system before and after the crystallization of $0.5 \mathrm{Si}$ sample were 5.56 and 8.20 , respectively).

Figure 3 and Table 3 show the $\mathrm{N}_{2}$ adsorption-desorption isotherms, specific surface areas, and pore volumes of the samples with different Si contents. All three samples displayed a high micropore surface area and micropore volume. Moreover, the outer specific surface area and mesopore volume of the samples increased with the increase of silicon contents, which would be due to the rough grain surface of the samples with high silicon contents, as revealed by the SEM images.

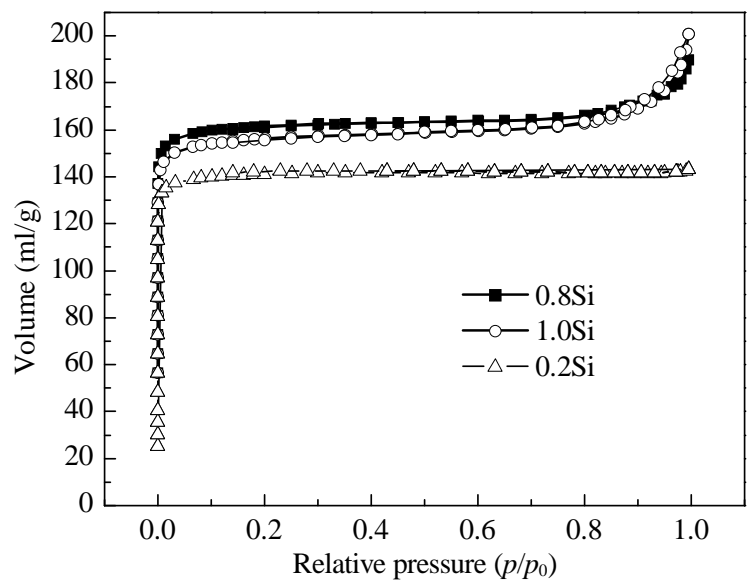

Fig. 3. $\mathrm{N}_{2}$ adsorption-desorption isotherms of the SAPO-35 samples with different Si contents.

Table 3

Pore structure parameters of the SAPO-35 samples with different $\mathrm{Si}$ contents.

\begin{tabular}{lccccccc}
\hline \multirow{2}{*}{ Sample } & \multicolumn{3}{c}{ Surface area $\left(\mathrm{m}^{2} / \mathrm{g}\right)$} & & \multicolumn{3}{c}{ Pore volume $\left(\mathrm{cm}^{3} / \mathrm{g}\right)$} \\
\cline { 2 - 4 } \cline { 6 - 8 } & Micropore & External & Total & & Micropore & Mesopore & Total \\
\hline $0.2 \mathrm{Si}$ & 443.5 & 26.3 & 469.7 & & 0.22 & 0.01 & 0.21 \\
$0.8 \mathrm{Si}$ & 497.4 & 41.0 & 538.4 & & 0.23 & 0.05 & 0.28 \\
$1.0 \mathrm{Si}$ & 475.4 & 45.8 & 521.2 & & 0.22 & 0.07 & 0.29 \\
\hline
\end{tabular}

\subsection{Methanol conversion by SAPO-35 molecular sieve with different Si contents}

0.1Si, $0.3 \mathrm{Si}$, and $0.5 \mathrm{Si}$ samples were selected for the study of methanol conversion. The results are shown in Fig. 4 and Table 4. The results of the MTO reaction on SAPO-34 (elemental composition is $\mathrm{Si}_{0.086} \mathrm{Al}_{0.493} \mathrm{P}_{0.421}$ ) are also listed in Table 4 for comparison. During an initial period, the conversion of methanol on SAPO-35 with different Si contents was maintained at above $99 \%$. The conversion decreased as the reaction time increased and the higher the Si content, the faster the conversion of methanol dropped. The selectivity for ethylene of these molecular sieves gradually rose as the reaction time increased, while the selectivity for propylene decreased. Compared with SAPO-34, SAPO-35 exhibited the characteristic of fast deactivation.

The MTO reaction is a typical acid catalyzed reaction, and the acidity of the molecular sieve plays an important role on the lifetime and the selectivity to light olefins. We determined the amount of Brönsted acid of the three SAPO-35 samples using 1H MAS NMR (shown in Table 5). Generally, the density of Brönsted acid sites increased in the samples with the increase of the Si contents. Both are almost in a linear relationship. The higher acid density in the samples with higher Si content caused serious side reactions, such as coke deposition and the hydrogen transfer reaction, which shortened the life time of the catalyst and generated more methane and propane. Moreover, the deposited coke species gradually formed during the reaction will decrease the cage size of the molecular sieves, reduce the generation and diffusion rates of molecules with larger diameters, and consequently increase the selectivity for ethylene and decrease the selectivity for propylene.

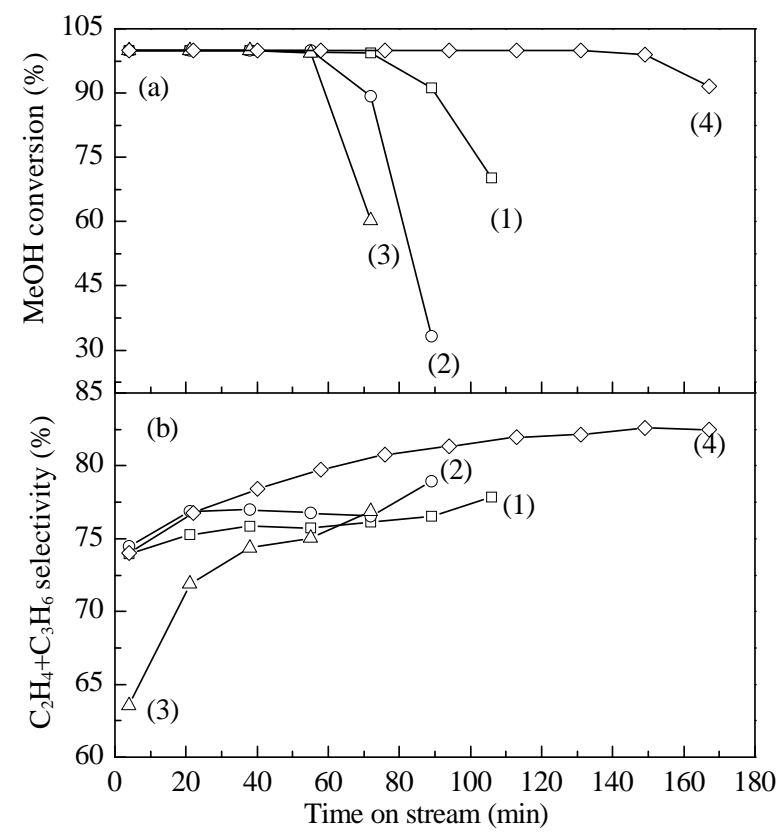

Fig. 4. $\mathrm{CH}_{3} \mathrm{OH}$ conversion (a) and $\mathrm{C}_{2} \mathrm{H}_{4}+\mathrm{C}_{3} \mathrm{H}_{6}$ selectivity (b) in the MTO reaction over SAPO-35 and SAPO-34. (1) $0.1 \mathrm{Si}$; (2) $0.3 \mathrm{Si}$; (3) $0.5 \mathrm{Si}$; (4) SAPO-34. Reaction condition: $450{ }^{\circ} \mathrm{C}, 40 \% \mathrm{CH}_{3} \mathrm{OH}$ solution (SAPO-35, $\mathrm{WHSV}=2 \mathrm{~h}^{-1}$; SAPO-34, WHSV $=4 \mathrm{~h}^{-1}$ ). 
Table 4

MTO results over SAPO-35 and SAPO-34 molecular sieves.

\begin{tabular}{|c|c|c|c|c|c|c|c|c|c|}
\hline \multirow{2}{*}{ Sample } & \multirow{2}{*}{$\begin{array}{c}\text { TOS } \\
\text { (min) }\end{array}$} & \multicolumn{8}{|c|}{ Selectivity (wt\%) } \\
\hline & & $\mathrm{CH}_{4}$ & $\mathrm{C}_{2} \mathrm{H}_{4}$ & $\mathrm{C}_{2} \mathrm{H}_{6}$ & $\mathrm{C}_{3} \mathrm{H}_{6}$ & $\mathrm{C}_{3} \mathrm{H}_{8}$ & $\mathrm{C}_{4}$ & $\mathrm{C}_{5+}$ & $\mathrm{C}_{2}=+\mathrm{C}_{3}=$ \\
\hline \multirow[t]{2}{*}{$0.1 \mathrm{Si}$} & 4 & 2.37 & 37.80 & 0.27 & 36.17 & 1.05 & 10.42 & 11.87 & 73.96 \\
\hline & $72^{a}$ & 2.66 & 43.85 & 1.02 & 32.30 & 1.41 & 9.24 & 9.43 & 76.16 \\
\hline \multirow[t]{2}{*}{$0.3 \mathrm{Si}$} & 4 & 2.71 & 33.94 & 0.30 & 40.55 & 1.31 & 12.46 & 8.69 & 74.50 \\
\hline & $55^{a}$ & 3.35 & 41.38 & 1.11 & 35.38 & 1.48 & 9.13 & 8.10 & 76.75 \\
\hline \multirow[t]{2}{*}{$0.5 \mathrm{Si}$} & 4 & 3.43 & 29.04 & 0.89 & 34.48 & 2.94 & 13.13 & 16.07 & 63.53 \\
\hline & $55^{\mathrm{a}}$ & 3.43 & 42.09 & 1.48 & 32.95 & 1.88 & 8.90 & 9.16 & 75.05 \\
\hline \multirow[t]{2}{*}{ SAPO-34b } & 4 & 0.96 & 33.61 & 0.65 & 40.38 & 4.63 & 15.64 & 4.08 & 74.00 \\
\hline & $131^{\mathrm{a}}$ & 1.49 & 43.32 & 0.62 & 38.80 & 1.54 & 11.03 & 3.10 & 82.12 \\
\hline
\end{tabular}

Reaction condition: WHSV $=2 \mathrm{~h}^{-1}, 450{ }^{\circ} \mathrm{C}, 40 \% \mathrm{CH}_{3} \mathrm{OH}$ solution.

a The catalyst lifetime, which is defined as the reaction duration with $>99 \% \mathrm{CH}_{3} \mathrm{OH}$ conversion.

b Reaction condition: WHSV $=4 \mathrm{~h}^{-1}, 450{ }^{\circ} \mathrm{C}, 40 \% \mathrm{CH}_{3} \mathrm{OH}$ solution (elemental composition of SAPO-34: $\mathrm{Si}_{0.086} \mathrm{Al}_{0.493} \mathrm{P}_{0.421}$ ).

\subsection{Analysis of the deposited coke species formed in the MTO reaction over SAPO-35 and SAPO-34}

The fast deactivation of SAPO-35 molecular sieve in the methanol conversion reaction indicated that the deposited coke species and their evolution with reaction time on SAPO-35 is different from those on SAPO-34. We selected 0.3Si SAPO-35 to study the deposited coke species following the reaction time and compared these with those generated on SAPO-34. The organic species extracted from the catalysts were analyzed by GC-MS (Fig. 5).

The organic species initially produced on SAPO-35 (15 min) were mostly toluene, xylene and trimethylbenzene. As the reaction time increased to $32 \mathrm{~min}$, the methanol conversion decreased from $98.49 \%$ to $76.37 \%$, and organic species with a larger molecular size, such as naphthalene and methyl naphthalene, started to appear in the deposited coke species. When the reaction time was $83 \mathrm{~min}$, the methanol conversion further decreased to $10.88 \%$. Among the deposited coke species, the signals of naphthalene and methyl naphthalene obviously increased, and a small amount of multiple methylated naphthalene and anthracene dihydride appeared in addition to toluene, xylene and trimethylbenzene. The organic species during the early stage $(21 \mathrm{~min}$ ) of methanol conversion over SAPO-34 molecular sieve were mainly trimethylbenzene, tetramethylbenzene, naphthalene, methyl naphthalene and dimethyl naphthalene. When the reaction time was $72 \mathrm{~min}$, the methanol conversion was still maintained at a high level $(98.57 \%)$. Coke species such as tetramethylbenzene, naphthalene, methylnaphthalene and dimethylnaphthalene were enhanced, and new signals corresponding to trimethylnaphthalene, phenanthrene and pyrene appeared. At the stage of nearly complete deactivation of SAPO-34 (447 min, 33.46\% methanol conversion), methyl benzene compounds disappeared. A significant change in the relative amounts of the other organic species occurred, and the polycyclic aromatic hydrocarbon

Table 5

Concentration of Brönsted acid sites in SAPO-35 molecular sieves calculated from ${ }^{1} \mathrm{H}$ MAS NMR.

\begin{tabular}{lc}
\hline Sample & B acid sites $(\mathrm{mmol} / \mathrm{g})$ \\
\hline $0.1 \mathrm{Si}$ & 0.54 \\
$0.3 \mathrm{Si}$ & 0.97 \\
$0.5 \mathrm{Si}$ & 1.20 \\
\hline
\end{tabular}

phenanthrene and pyrene and their methyl substituted derivatives became the major coke species. By comparing the evolution of the organic species in SAPO-35 and SAPO-34, a common characteristic is that the main organic species generated in the initial stage were methylated benzene compounds which gradually changed to bulky aromatic hydrocarbons. The final coke molecules in SAPO-34 were significantly larger than those in SAPO-35.

The hydrocarbon pool mechanism is a widely recognized MTO reaction mechanism. Much experimental results indicated that the multiply methylated benzene (methyl substituents $>3$ )
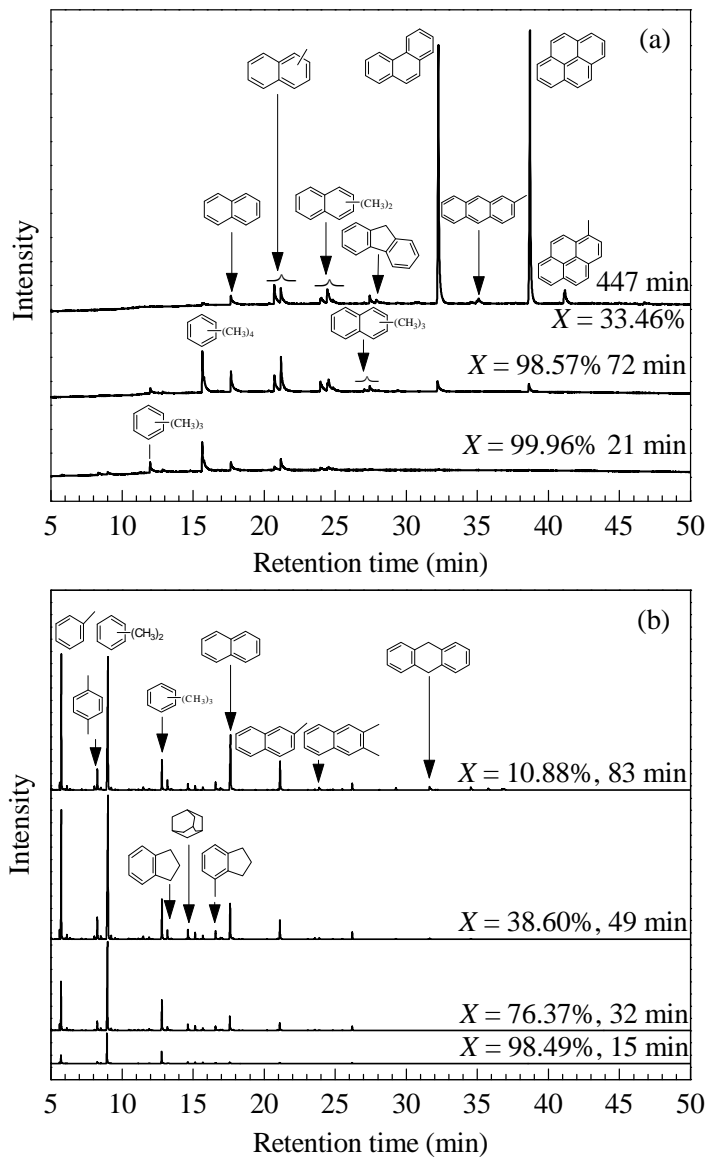

Fig. 5. Coke species in SAPO-34 (a) and SAPO-35 (b) in the MTO reaction. Reaction condition: WHSV $=4 \mathrm{~h}^{-1}, 400{ }^{\circ} \mathrm{C}, 40 \% \mathrm{CH}_{3} \mathrm{OH}$ solution; $X$ refers to the $\mathrm{CH}_{3} \mathrm{OH}$ conversion in the reaction. 


\section{Graphical Abstract}

Chin. J. Catal., 2013, 34: 798-807 doi: 10.1016/S1872-2067(12)60557-9

Synthesis of SAPO-35 molecular sieve and its catalytic properties in the methanol-to-olefins reaction

LI Bing, TIAN Peng, LI Jinzhe, CHEN Jingrun, YUAN Yangyang, SU Xiong, FAN Dong, WEI Yingxu, QI Yue, LIU Zhongmin*

Dalian Institute of Chemical Physics, Chinese Academy of Sciences; University of Chinese Academy of Sciences

SAPO-35 was hydrothermally synthesized using hexamethyleneimine as the template. The coke species in the MTO reaction over both SAPO-35 and SAPO-34 were investigated and correlated with their cage size.

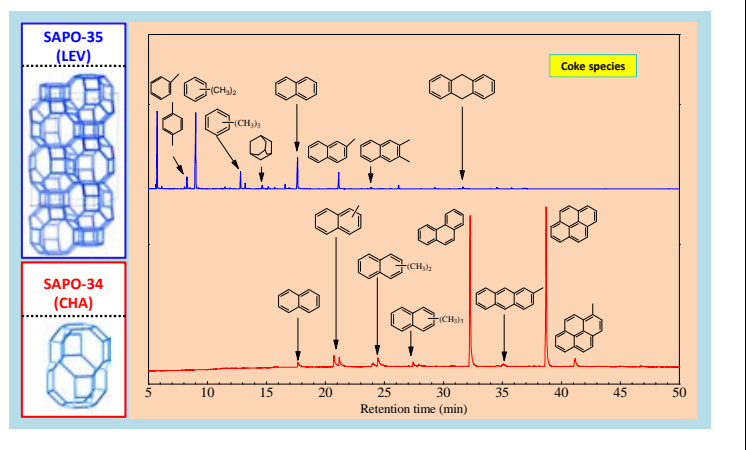

is a hydrocarbon pool active center, on which the methylation of methanol/diethyl ether occurred to form ethylene and propylene, while the resulting less methylated benzene is re-methylated to start a new catalytic cycle [15,16,24-27]. In the present experiments, in the initial stage of reaction the existence of some hydrocarbon pool active species (multiply methylated benzenes) were observed in SAPO-34, whereas the coke species was dominated by less methylated benzenes in SAPO-35. With increased reaction time, at the stage of nearly complete deactivation, the main coke species in SAPO-34 were bulky aromatic hydrocarbons such as phenanthrene and pyrene (generated from ring condensation by hydrogen transfer from methylbenzene and methylnaphthalene), while the coke species in SAPO-35 were methylbenzene, naphthalene and methylnaphthalene. The difference in the coke species of SAPO-35 and SAPO-34 is probably related to their structures. The CHA cage of SAPO-34 $(0.67 \mathrm{~nm} \times 0.67 \mathrm{~nm} \times 1.0 \mathrm{~nm})$ is larger than the LEV cage of SAPO-35 $(0.63 \mathrm{~nm} \times 0.63 \mathrm{~nm} \times 0.73$ $\mathrm{nm})$. The smaller cage of SAPO-35 restricted the formation of the hydrocarbon pool active species (multiply methylated benzene) and deactivated coke species (macromolecular fused-ring aromatic hydrocarbon). Also, it has a smaller accommodation capacity for deactivated coke species, which thus resulted in the rapid deactivation. The lack of hydrocarbon pool active species also led to the relatively low ethylene and propylene selectivity with SAPO-35. Moreover, it is worth noting that during the reaction, the organic compounds deposited in SAPO-35 always contained a small amount of saturated cycloalkane adamantane compounds. In our recent research on the coke species in SAPO-34 in the MTO reaction [28], we reported that adamantane compounds are the coke species in the low temperature reaction $\left(\leq 350{ }^{\circ} \mathrm{C}\right)$, which were gradually transformed into naphthalene and substituted naphthalene species at elevated temperatures. In this experiment, the reaction temperature was $400{ }^{\circ} \mathrm{C}$, so the existence of adamantane compounds in SAPO-35 once again demonstrated that the different cage size of the molecular sieve has a large influence on the generation and stability of the coke species.

\section{Conclusions}

SAPO-35 molecular sieves with different Si contents were hydrothermally synthesized. The yield of solid sample increased with the increase of Si content in the synthesis gel. The crystallinity of the sample increased first and then decreased as the $\mathrm{Si}$ content increased. $0.3 \mathrm{Si}$ sample exhibited the highest crystallinity. The Si incorporation degree showed a dropping trend when the silica content rose. The surface of SAPO-35 crystals with a high silica content was rough. In particular, 1.0Si showed the characteristic of a core-shell structure, which could be due to secondary crystallization on the rough surface. SAPO-35 showed fast deactivation than SAPO-34 in the MTO reaction, and a higher silica content will cause faster deactivation. The main reason is that the higher Brönsted acid concentration in the sample with higher silica content led to more side reactions such as coke deposition and hydrogen transfer. By comparing and analyzing the deposited coke species formed in SAPO-35 and SAPO-34 during the MTO reaction, we concluded that the smaller cage of SAPO-35 limited the generation of hydrocarbon pool active species (polymethylbenzens) and macromolecular coke species (polyaromatic hydrocarbons). Moreover, the smaller cage of SAPO-35 had a lower capacity to accommodate deposited coke species. These two reasons resulted in the faster deactivation of SAPO-35.

\section{References}

[1] Lok B M, Messina C A, Patton R L, Gajek R T, Cannan T R, Flanigen E M. US Patent 4440871.1984

[2] Fu Y, Wang L F, Tan Y X, Ji H B. Chem React Eng Technol (付晔, 王 乐夫, 谭宇新, 纪红兵. 化学反应工程与工艺), 2000, 16(1): 55

[3] http://www.iza-structure.org/databases/

[4] Zhu Zh D, Hartmann M, Kevan L. Chem Mater, 2000, 12: 2781

[5] Jeon H Y, Shin C H, Jung H J, Hong S B. Appl Catal A, 2006, 305: 70

[6] Djieugoue M A, Prakash A M, Kevan L. J Phys Chem B, 2000, 104: 6452

[7] Venkatathri N, Yoo J W. Appl Catal A, 2008, 340: 265

[8] Cheung O, Liu Q L, Bacsik Z, Hedin N. Microporous Mesoporous Mater, 2012, 156: 90

[9] Falconer J L, Li Sh G, Noble R D. US Patent 20050204916A1. 2005

[10] Liu G Y, Tian P, Liu Zh M. Progr Chem (刘广宇, 田鹏, 刘中民. 化学 进展), 2010, 22: 1531

[11] Zhang J Ch, Zhang H B, Yang X Y, Huang Zh, Cao W L. J Nat Gas Chem, 2011, 20: 266 
[12] Liu G Y, Tian P, Xia Q H, Liu Zh M. J Nat Gas Chem, 2012, 21: 431

[13] Nawaz S, Kolboe S, Stöcker M. Stud Surf Sci Catal, 1994, 81: 393

[14] Chen J Sh, Wright P A, Thomas J M, Natarajan S, Marchese L, Bradley S M, Sankar G, Catlow C R A, Gai-Boyes P L. J Phys Chem, 1994, 98: 10216

[15] Yuan C Y, Wei Y X, Li J Zh, Xu Sh T, Chen J R, Zhou Y, Wang Q Y, Xu L, Liu Zh M. Chin J Catal (袁翠峪, 魏迎旭, 李金哲, 徐舒涛, 陈景 润, 周游, 王全义, 许磊, 刘中民. 催化学报), 2012, 33: 367

[16] Hereijgers B P C, Bleken F, Nilsen M H, Svelle S, Lillerud K P, Bjørgen M, Weckhuysen B M, Olsbye U. J Catal, 2009, 264: 77

[17] Zhang F M, Kuang X H, Li L Sh, Shu X T, Wang W D, Qin F M (张风 美, 匡晓辉, 李黎声, 舒兴田, 王卫东, 秦凤明), CN Patent 101397 143. 2009

[18] Guisnet M. J Mol Catal A, 2002, 182-183: 367

[19] Guisnet M, Costa L, Ribeiro F R. J Mol Catal A, 2009, 305: 69
[20] Prakash A M, Hartmann M, Kevan L. Chem Mater, 1998, 10: 932

[21] Zhang D Zh. [PhD Dissertation]. Dalian: Dalian Institute of Chemical Physics, CAS (张大治. [博士学位论文]. 大连: 中国科学院大连 化学物理研究所), 2007

[22] Sastre G, Lewis D W, Catlow C R A.J Phys Chem, 1996, 100: 6722

[23] Liu G Y, Tian P, Zhang Y, Li J Zh, Xu L, Meng Sh H, Liu Zh M. Microporous Mesoporous Mater, 2008, 114: 416

[24] Wang J D, Yu X B, Liu Y, Yang Y R. Progr Chem (王靖岱, 虞贤波, 刘 烨，阳永荣. 化学进展), 2009, 21: 1757

[25] Arstad B, Kolboe S. J Am Chem Soc, 2001, 123: 8137

[26] Arstad B, Kolboe S. Catal Lett, 2001, 71: 209

[27] Lesthaeghe D, De Sterck B, Van Speybroeck V, Marin G B, Waroquier M. Angew Chem, Int Ed, 2007, 46: 1311

[28] Wei Y X, Li J Zh, Yuan C Y, Xu Sh T, Zhou Y, Chen J R, Wang Q Y, Zhang Q, Liu Zh M. Chem Commun, 2012, 48: 3082

\title{
SAPO-35分子篮的合成及其甲醇制烯烃反应性能
}

\author{
李 冰 $^{\mathrm{a}}$, 田 鹏 ${ }^{\mathrm{a}}$ ，李金哲 ${ }^{\mathrm{a}}$ ，陈景润 ${ }^{\mathrm{a}, \mathrm{b}}$ ，袁扬扬 ${ }^{\mathrm{a}, \mathrm{b}}$ ，苏 雄 ${ }^{\mathrm{a}, \mathrm{b}}$ ，樊 栋 ${ }^{\mathrm{a}, \mathrm{b}}$, \\ 魏迎旭 ${ }^{\mathrm{a}}$, 齐越, 刘中民 , $^{\mathrm{a}}$ \\ a中国科学院大连化学物理研究所洁净能源国家实验室(筹), 甲醇制烯烃国家工程实验室, 辽宁大连116023 \\ b中国科学院大学, 北京100049
}

摘要: 以六亚甲基亚胺为模板剂,采用水热法合成了不同硅含量的磷酸硅铝分子篮SAPO-35, 并利用X射线衍射、X射线苂光光谱、 扫描电镜、固体核磁、X射线光电子能谱和 $\mathrm{N}_{2}$ 吸附-脱附等方法对样品进行了表征. 研究了不同硅含量的SAPO-35分子篮在甲醇转 化制烯烃反应中的催化行为, 同时对比分析了具有相近硅含量的SAPO-35和SAPO-34分子篎在甲醇转化反应过程中积炭物种随 反应时间的演变特征, 尝试将分子篮结构和其积炭失活行为进行了关联.

关键词: SAPO-35; 甲醇制烯烃; SAPO-34; 积炭物种; 失活

收稿日期: 2012-12-30. 接受日期: 2013-01-30. 出版日期: 2013-04-20.

*通讯联系人. 电话/传真: (0411)84379335; 电子信箱: liuzm@dicp.ac.cn

本文的英文电子版由Elsevier出版社在ScienceDirect上出版(http://www.sciencedirect.com/science/journal/18722067).

\section{1. 前言}

磷酸硅铝系列分子篮(SAPO-n)由美国联合碳化物 公司(UCC)于1984年合成并报道 ${ }^{[1]}$. 由于SAPO分子篮具 有温和可调的酸性和不同的孔道结构, 在多个化工行业 展现出广阔的应用前景 ${ }^{[2]}$. SAPO-35作为其中的一员, 晶 体结构为插晶菱沸石型 $(\mathrm{LEV})$, 孔径 $0.36 \mathrm{~nm} \times 0.48 \mathrm{~nm}$, 属小孔分子篮. SAPO-35的骨架结构可看作是LEV笼通 过单六元环和双六元环连接而成, 它含有两种不同的 $\mathrm{T}$ 原子位置, 分别在双六元环和单六元环中, 两者的分布比 例为 $2: 1^{[3]}$. 依据SAPO-35分子篮独特的结构特点, 研究者 尝试将其用作甲醇转化反应和氨甲基化反应的催化 剂 ${ }^{[4 \sim 7]}$ 以及用于 $\mathrm{CO}_{2} / \mathrm{CH}_{4}$ 吸附分离 ${ }^{[8,9]}$.

甲醇转化制烯烃(MTO) 是以煤或天然气为原料制 取低碳烯烃的关键过程. ZSM-5分子篮及具有八元环孔 道和cha笼的SAPO-34分子篮在MTO反应中表现出优异 的催化性能 ${ }^{[6,7,10 \sim 12]}$. 此外, 其它八元环孔道的小孔分子
笁, 如SAPO-17, SAPO-18和SAPO-35也被尝试用作MTO 反应的催化剂 ${ }^{[7,13,14]}$. 研究表明, 与 SAPO-34 相比, SAPO-35分子篮在MTO反应中表现出较快的积炭失 活 ${ }^{[4,6]}$. 目前, SAPO-34分子篮上甲醇转化失活过程(积炭 物种)随反应时间和反应温度等条件变化的规律和特点 已经相对清楚 ${ }^{[15,16]}$, 但是到目前为止, 还未见到SAPO-35 分子篮上甲醇转化失活过程的研究. 两者催化性能的差 别推测与自身结构的差异有关. 对SAPO-35积炭失活过 程的研究分析将有助于深入理解分子篮笼结构变化对 反应过程和积炭物种的影响.

本文以六亚甲基亚胺为模板剂, 采用水热法合成出 不同硅含量的SAPO-35分子篎, 详细研究了硅含量变化 对最终产品物理化学性质的影响, 并选取了 3 个具有不 同硅含量的SAPO-35分子篮作为MTO反应的催化剂, 考 察了酸性质变化对反应结果的影响. 另外, 还对比研究 了具有相近硅含量的SAPO-35和SAPO-34在MTO反应 过程中积炭物种随反应时间的变化, 尝试将分子篮结构 
和其积炭失活行为进行关联.

\section{2. 实验部分}

\section{1. 分子篮的合成}

SAPO-35分子笁的合成参照文献[17]. 以拟薄水铝 石粉 $\left(w\left(\mathrm{Al}_{2} \mathrm{O}_{3}\right)=70 \%\right.$, 质量分数, 下同)、硅溶胶 $\left(w\left(\mathrm{SiO}_{2}\right)=\right.$ $31.1 \%)$ 和磷酸 $\left(w\left(\mathrm{H}_{3} \mathrm{PO}_{4}\right)=85 \%\right)$ 分别为铝源、硅源和磷 源, 以六亚甲基亚胺(HMI, 化学纯)为模板剂. 各组分摩 尔配比为 $0.96 \mathrm{P}_{2} \mathrm{O}_{5}: 1.0 \mathrm{Al}_{2} \mathrm{O}_{3}: n \mathrm{niO}_{2}: 1.51 \mathrm{HMT}: 55.47 \mathrm{H}_{2} \mathrm{O}$ $(n=0.1,0.2,0.3,0.5,0.8,1.0)$. 具体配料过程如下: 依次向 烧杯中加入去离子水、铝源、磷源、硅源和有机胺, 搅 拌均匀后, 将初始凝胶移至 $100 \mathrm{ml}$ 不锈钢合成釜中, 密封 后加热至 $200{ }^{\circ} \mathrm{C}$ 恒温晶化 $24 \mathrm{~h}$. 晶化完成后将产物离心, 固体样品用水洗至中性后 $120^{\circ} \mathrm{C}$ 烘干备用. 不同 $\mathrm{Si}$ 含量 的样品记为 $n S i(n=0.1,0.2,0.3,0.5,0.8,1.0)$.

\section{2. 分子篮的表征}

$\mathrm{X}$ 射线粉末衍射 (XRD) 物相分析在 PANalytical X'Pert PRO 型X射线衍射仪上进行, $\mathrm{Cu}$ 靶 $K_{\alpha}$ 辐射源 $(\lambda=$ $0.15418 \mathrm{~nm}$ ), 电压 $40 \mathrm{kV}$, 电流 $40 \mathrm{~mA}$. 采用Philips 公司的 Magix 2424X型射线荧光(XRF)光谱仪对样品进行元素 分析. 样品形貌在Hitachi S-3400N型扫描电子显微镜 (SEM) 上观察. X 射线光电子能谱 (XPS) 采用 Thermo ESCALAB 250Xi型X射线光电子能谱仪进行测定(以单 色化 $\mathrm{Al} K_{\alpha}$ 为激发源), 以样品表面 $\mathrm{Al}_{2} \mathrm{O}_{3}$ 的 $\mathrm{Al} 2 p=74.7$ $\mathrm{eV}$ 为内标来校正样品表面的荷电. $\mathrm{N}_{2}$ 吸附-脱附实验在 美国麦克ASAP2010型物理吸附仪上进行.

${ }^{1} \mathrm{H}$ 固体核磁共振 $\left({ }^{1} \mathrm{H}\right.$ MAS NMR $)$ 谱在Bruker Avance III-600型固体核磁共振谱仪上测定, 使用 $4 \mathrm{~mm}$ 探头. ${ }^{1} \mathrm{H}$ 的共振频率为600.13 MHz, 采用单脉冲 (one pulse)程序, $\pi / 2$ 脉宽为 $4.4 \mu \mathrm{s}$, 弛豫延迟为 $10 \mathrm{~s}$, 转速为 $12 \mathrm{kHz}$, 采样次 数为 32 次. 实验前, 所有样品在 $400{ }^{\circ} \mathrm{C}$, 低于 $10^{-3} \mathrm{~Pa}$ 真空 脱水 $20 \mathrm{~h}$ 以上, 以脱除吸附在分子篮中的水和杂质. 样品 在 $\mathrm{N}_{2}$ 手套箱中转移到核磁转子中待测. ${ }^{1} \mathrm{H}$ MAS NMR谱 的定量分析方法如下: 以金刚烷为外标物, 首先获得标 样峰面积与质量关系的标准曲线. 在相同的采谱条件下 获得已知质量样品的 ${ }^{1} \mathrm{H}$ MAS NMR 谱, 根据 Gauss-Lowrance线型拟合获得 $\mathrm{B}$ 酸峰面积, 再根据标准 曲线获得样品的B酸密度.

\section{3. 催化性能评价}

采用常压固定床装置评价分子篮样品上甲醇转化 反应性能. 将1.2 g焙烧后的催化剂样品(40 60目)装填在 反应器中, 于 $\mathrm{N}_{2}$ 气氛下升温至 $520^{\circ} \mathrm{C}$ 吹扫 $30 \mathrm{~min}$ 后降至
反应温度, 然后停止通载气, 并采用微量洜洜进甲醇溶液 $(w=40 \%)$. 产物采用气相色谱仪(Agilent7890A型)进行 在线分析, PoraPLOT Q-HT毛细管色谱柱, FID检测器.

\section{4. 积炭样品的收集及积炭物种分析}

反应过程同2.3节, 在反应一定时间后停止进料, 快 速卸出催化剂至液氮中急冷后保存, 得到相应反应时间 的积炭样品.

积炭物种的定性分析采用Guisnet法 ${ }^{[18,19]}$. 分别称取 $50 \mathrm{mg}$ 催化剂装入聚四氟乙烯瓶中, 加入 $1 \mathrm{ml}$ 的HF水溶 液 (20\%), 摇匀后静置 $1 \mathrm{~h}$, 样品溶解后, 再加入 $0.5 \mathrm{ml}$ 二氯 甲烷, 静置 $5 \mathrm{~min}$ 后, 加入 $\mathrm{NaOH}$ 溶液并摇匀, 将混合物转移 到分液漏斗中振荡静置, 将下层萃取液取出滴入微量进 样瓶中备分析用. 采用安捷伦色质谱 (Agilent 7890-5975C MSD)进行分析, HP-5毛细管色谱柱. 积炭物 种定性采用Nist08数据库.

\section{3. 结果与讨论}

\section{1. 不同硅含量SAPO-35分子篮的合成与表征结果}

合成SAPO-35样品的XRD谱见图1. 由图可知, 所制 系列不同硅含量的样品均为具有 LEV 结构的 SAPO-35 分子䇻 ${ }^{[7,20]}$. 表1列出了它们的相对结晶度、相对收率和 元素组成. 可以看出, 随着初始凝胶中 $\mathrm{SiO}_{2}$ 用量的增加, 所得样品的固体收率逐渐上升; 而样品的相对结晶度则 先升高后降低, 其中以 $0.3 \mathrm{Si}$ 样品的最高. 我们在 SAPO-34的合成研究中也发现, 初始凝胶中硅含量在 0.2 到 0.3 时所得样品的相对结晶度最高 ${ }^{[21]}$. 这说明凝胶中 的硅含量不仅影响产品的组成, 同时对分子篮的结晶度 也有影响. 另外, XRF结果显示, SAPO-35中硅含量随着 初始凝胶中硅含量的增加而上升. 为了进一步关联投料 硅含量与所得样品中硅含量的关系, 这里提出硅进入率 的概念, 将其定义为 $[\mathrm{Si} /(\mathrm{Si}+\mathrm{Al}+\mathrm{P})]_{\text {产物 }}[\mathrm{Si} /(\mathrm{Si}+\mathrm{Al}+\mathrm{P})]_{\text {初始疑胶 }}$ (见表1). 可以看出, 随着投料硅含量的增加, 所得 SAPO-35样品中的硅进入率逐渐下降. 其中 $0.1 \mathrm{Si}$ 样品的 硅进入率最高为 1.82 ; 当初始凝胶中硅含量大于 0.3 时, 硅进入率开始小于 1 ; 至1.0时仅为 0.7 . 因此, 可以认为正 是由于低硅样品中高的硅进入率导致了其较低的固体 收率. 文献[22]运用晶格模拟技术(Lattice simulation techniques)计算了SAPO-5分子篮中硅进入骨架能量的 变化, 发现分散度高的单取代硅是最稳定的, 其次是 $5 \mathrm{Si}$ 和8Si岛, 即随着硅取代量的增加, 硅进入骨架所需能量 也相应增大, 从而导致硅进入骨架的能力降低. 这与本 文结果一致. 
图2为不同硅含量的SAPO-35样品的SEM照片. 可 以看出, 各样品的晶粒均呈典型的菱方形貌. 硅含量低 时,所得分子篮表面较光滑; 硅含量升至0.8后晶体表面 变得粗粮, 出现不规则的小孔洞; 硅含量为 1.0 时, 晶体表 面被小颗粒包裹, 呈现类似核壳结构的形貌,推测与粗粘 晶体表面的二次晶体生长有关, 但也不能排除表面壳层 可能是凝胶中过多的无定形氧化硅在晶体表面富集形 成. 我们进一步采用XPS对 $0.5 \mathrm{Si}$ 和1.0Si样品的表面组成 进行了分析(见表2). 可以看到, 两个样品的晶体表面均 由氧化硅、氧化磷和氧化铝组成, 表面的相对硅含量高 于体相, 且硅含量高的样品表面富硅程度更高. 由此推 测, 1.0Si样品晶粒外表面的壳层形成应该为粗糙晶体表 面的二次晶体生长所致. 同时, 依据XPS揭示的SAPO-35 晶体表面富硅现象, 我们认为SAPO-35晶体中硅的分布 可能是不均匀的, 即硅含量从内向外逐渐增加. 我们在 对DEA为模板剂合成SAPO-34的晶化过程研究中也曾 发现这种情况 ${ }^{[23]}$. 这主要原因是SAPO分子篮合成过程 中凝胶的 $\mathrm{pH}$ 值逐渐增加所致. 因为 $\mathrm{pH}$ 的增加会促进凝 胶体系中硅源的解聚, 使得硅参与进入分子篮骨架的能 力增加(在本文的合成体系中, $0.5 \mathrm{Si}$ 样品晶化前后的凝胶 $\mathrm{pH}$ 值分别为 5.56 和 8.20$)$.

图3和表3分别给出了不同 $\mathrm{Si}$ 含量样品的 $\mathrm{N}_{2}$ 吸附-脱 附曲线和比表面积、孔体积. 可以看出, 三个样品均具有 较高的微孔比表面积和微孔体积. 另外, 样品的外比表 面积和介孔体积随着硅含量的增加而增大. 这应该与 SEM照片揭示的高硅样品的晶粒表面变得粗䊁有关.

\section{2. 不同硅含量的SAPO-35分子篮上MTO反应性能}

选取 $0.1 \mathrm{Si}, 0.3 \mathrm{Si}$ 和 $0.5 \mathrm{Si}$ 样品用于 MTO反应中, 结果 示于图4和表4. 为了比较, 表4也列出了典型MTO催化剂 SAPO-34 (元素组成 $\mathrm{Si}_{0.086} \mathrm{Al}_{0.493} \mathrm{P}_{0.421}$ ) 上的反应结果. 可 以看出, 不同硅含量 SAPO-35样品上甲醇转化率在一定 时间内都可以保持在 $99 \%$ 以上; 随着反应时间的延长, 甲 醇转化率降低, 硅含量越高的样品, 其上甲醇转化率降低 速度越快. 不同硅含量样品上乙烯选择性均随反应时间 延长而逐渐上升, 而丙烯选择性逐渐下降. 比较而言, SAPO-35表现出快速失活的特征,最高的乙烯-丙烯选择 性也低于SAPO-34.

MTO反应是典型的酸催化过程, 分子笁的酸性对其 稳定性和低碳烯烃选择性的影响很大. 本文采用 ${ }^{1} \mathrm{H}$ MAS NMR测定了3个不同硅含量的SAPO-35样品中B酸 量(见表5). 可以看出, 随着样品中硅含量的增加, B酸中 心密度增大, 其幅度基本与固体样品中所含的硅量一致
因此, 高硅含量样品中高的酸中心密度导致了催化剂上 较严重的副反应(如积炭和氢转移反应), 使得催化剂寿 命缩短, 同时生成较多的甲烷和丙烷. 另外, 反应过程中 催化剂上积炭物种的逐渐生成,将会降低分子篮的孔笼 尺寸, 有利于分子直径较小的产物的生成和扩散, 从而使 得乙烯选择性增加,而丙烯选择性降低.

\subsection{SAPO-35和SAPO-34分子篮在MTO反应中的积炭 物种}

SAPO-35分子篮在MTO反应中表现出的快速失活 的特征, 说明其积炭物种及其随反应时间的演变可能与 SAPO-34分子篮不同. 本文选取 $0.3 \mathrm{Si}$ 样品, 研究了其积 炭失活物种随反应时间的变化, 并与相同反应条件下具 有相近硅含量的SAPO-34分子篮进行了比较. 催化剂上 有机物种萃取分离后的色质联用分析结果示于图5.

SAPO-35分子篮上反应初期(15 min)检测到的有机 物种主要是少甲基取代苯,包括甲苯、二甲苯和三甲苯; 反应至 $32 \mathrm{~min}$ 时, 甲醇转化率从初期的 $98.49 \%$ 降至 $76.37 \%$, 同时积炭物种中开始出现菜和甲基荎等较大体 积的有机分子; 至 $83 \mathrm{~min}$ 时, 甲醇转化率降至 $10.88 \%$. 积 炭物种中除原有的少甲基取代苯外, 䒺和甲基菜的信号 有明显增强, 并且还出现了少量的多甲基取代荎和二氢 化葱. SAPO-34分子篮上甲醇转化初期(21 min)观察到 的有机物主要是三甲基苯、四甲基苯、菜、甲基萗和二 甲基芸等. 反应时间为 $72 \mathrm{~min}$ 时, 甲醇转化率依然维持在 98.57\%; 与初期相比,四甲基苯、萘、甲基萘和二甲基慕 的信号有所增强, 同时还出现了三甲基菜、菲和萠的信 号. SAPO-34接近完全失活阶段 (447 min, 甲醇转化率 33.46\%), 催化剂上沉积物中甲基苯类化合物已经基本消 失, 同时其它有机物的相对量也发生明显改变,稠环芳烃 菲和芘及其甲基取代物成为主要的积炭物种. 由此可见, SAPO-35和SAPO-34上有机沉积物种均从反应初期的甲 基取代苯逐渐增长为具有较大分子体积的芳烃类化合 物,但SAPO-34上最终积炭产物的分子体积明显更大.

到目前为止, 烃池机理是较广泛认可的MTO反应机 理. 大量实验表明,多甲基苯(甲基取代数大于 3 )是烃池 的活性中心, 它们通过与甲醇/二甲醚的甲基化形成乙烯 和丙烯, 本身形成少甲基苯后经过重新甲基化开始一个 新的催化循环 ${ }^{[15,16,24 ~ 27]}$. 在本文中, SAPO-34上反应初期 存在一定量的烃池活性物种多甲基苯, 而SAPO-35上的 很少, 积炭物种以少甲基苯为主. 随着反应时间的延长, 在催化剂接近完全失活阶段, SAPO-34上的积炭产物以 稠环芳烃菲和萠为主(来自于甲基苯和甲基荎积炭物种 
通过氢转移产生的环缩合反应), SAPO-35上则主要是 甲基苯、萗和甲基萗. 这可能与它们自身的结构有关. SAPO-34 分子篮中的 CHA 笼 $(0.67 \mathrm{~nm} \times 0.67 \mathrm{~nm} \times 1.0$ $\mathrm{nm})$ 要大于 SAPO-35 中的 LEV 笼 $(0.63 \mathrm{~nm} \times 0.63 \mathrm{~nm} \times$ $0.73 \mathrm{~nm}) . \mathrm{SAPO}-35$ 中较小的笼体积限制了烃池活性物 种多甲基苯和大分子积炭失活物种稠环芳烃的生成, 同 时它对积炭失活物种也具有较弱的容纳能力, 因而失活 较快, 烃池活性物种的缺乏也使得乙烯、丙烯选择性相 对较低. 另外, 值得注意的是, 反应过程中SAPO-35催化 剂上沉积的有机物中始终含有少量饱和环烷烃结构的 金刚烷类化合物. 我们近期对SAPO-34在MTO反应的积 炭物种研究中, 首次发现报道了金刚烷类化合物是低温 反应 $\left(\leqslant 350^{\circ} \mathrm{C}\right)$ 的积炭物种, 升高温度后其逐渐转变为 菜和取代菜类物种 ${ }^{[28]}$. 本文实验的反应温度为 $400{ }^{\circ} \mathrm{C}$, 金 刚烷类化合物在SAPO-35中的稳定存在再次说明分子 筛笼尺寸的变化对积炭物种的生成和稳定具有重要的 影响.

\section{4. 结论}

利用水热法合成了不同硅含量的SAPO-35分子篮, 发现随着合成凝胶中硅含量的增加, 样品的固体收率逐 渐上升; 样品的结晶度则先升高后降低, 其中 $0.3 \mathrm{Si}$ 样品 具有最高的相对结晶度; 硅进入骨架的能力随硅含量的 增加而下降. 高硅SAPO-35的晶体表面比较粗糙, 尤其是 1.0Si样品的晶体形貌呈核壳结构, 推测为粗䊁晶体表面 的二次晶体生长所致. 不同硅含量的SAPO-35样品在 MTO反应中都呈现较快速失活的特征, 且硅含量越高, 失活速度越快. 这主要是由于高硅样品中较高的B酸中 心密度导致了严重的积炭和氢转移反应等副反应. 对比 分析SAPO-35与SAPO-34在MTO反应过程所产生的积 炭物种, 发现SAPO-35中较小的笼体积限制了烃池活性 物种多甲基苯和大分子积炭失活物种多苯环化合物的 生成, 同时其对积炭失活物种也具有较弱的容纳能力, 从 而导致了较快速的失活. 